\title{
Reminiscência e alma Remêmora no Fédon de Platão
}

\author{
Rodolfo José Rocha Rachid ${ }^{1}$
}

Resumo: Pretende-se analisar o estatuto ontológico e epistemológico da alma cognitiva, no Fédon de Platão, a fim de evidenciar sua capacidade inata concernente à memória e à reminiscência, para a constituição da teoria platônica das Formas. Para esse propósito, visa-se a demonstrar que a atividade escrita de Platão ressalta a coexistência entre o discurso figurativo e o discurso racional, na qual ele desenvolve a dialética entre os gêneros sensível e inteligível. Assim, na primeira seção, a pesquisa escrutina a expressão mathésis anámnesis, o aprendizado é recordação, atestada previamente no Mênon e no Fédon, como condiçấo epistemológica fundamental para adquirir o conhecimento das ideias. Na seção seguinte, almeja-se explicar como a posse de uma sabedoria numinosa pela alma remêmora estabelece uma forma original de saber, que não pode ser adstrita em limites humanos, requerendo, para seu entendimento, uma nova abordagem hermenêutica, a qual se denomina hermenêutica cultual. Por fim, demonstra-se, na última seção, que o escopo fenomenológico do mito prevê uma semântica da visibilidade, pela qual Platão descreve a genuína natureza do logos filosófico, representado no encômio socrático da meléte thanátou.

Palavras-Chave: Teoria das Formas. Ontologia. Epistemologia. Alma remêmora. Discurso mítico.

A Léon Kossovitch

\section{INTRODUÇÃo}

Dos Diálogos platônicos, o Fédon assume relevância estratégica, à medida que enuncia preliminarmente no corpus o que sua fortuna crítica denominará ulteriormente de Teoria das Formas, conformando o momento inaugural da metafísica clássica. Por séculos, a leitura e interpretação do

${ }^{1}$ Doutor em Letras Clássicas pela FFLCH da Universidade de São Paulo (USP), São Paulo, SP - Brasil.

(D) https://orcid.org/0000-0001-7207-2909. E-mail: rodolforachid@uol.com.br.

https://doi.org/10.1590/0101-3173.2021.v44n4.26.p327

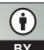

This is an open-access article distributed under the terms of the Creative Commons Attribution License. 


\title{
encômio socrático do exercício para a morte, a meléte thanátou, cindindo os campos ontológicos do sensível e do inteligível, projeta a figura de um Platão idealista, avesso à corporeidade, descurando dos componentes cultuais ${ }^{2}$ assim como mitopoéticos ${ }^{3}$ do texto do filósofo ateniense, entendidos como recursos
}

\begin{abstract}
2 Segundo Torrano (TORRANO, 2019, p. 43), “[...] por culto se entende a interpelação do divino no humano e o modo pelo qual o homem constitui formas a fim de manifestar essa interpelação." A interpelação socrática ao seu nume, atestada nos Diálogos, manifesta a postura cultual do dialético em relação ao caráter venerando da verdade. Por hermenêutica cultual, entendo o modelo hermenêutico de codificação das formas sagradas existentes na religião grega arcaica e clássica, presentes na pólis ateniense clássica, em uma linguagem que se pretende uma epistéme. Compreender Platão por uma hermenêutica cultual nâo significa entendê-lo por uma lógica apodítica que manifesta as irrevocáveis exigências de completude e consistência, prescrevendo na obra ausências de antinomias e lacunas, mas, antes, por um discurso no qual o plano conceitual se funda na interpretação das estruturas míticas do mundo grego, exemplificada pela correlação entre o ser, o conhecimento e a verdade, não denotando ainda a ulterior cisão entre o mítico e o lógico, o retórico e o epistêmico, o político e o cultual. $\mathrm{O}$ filósofo privilegiaria tanto a natureza do discurso oral e o seu consequente registro escrito, imagem do paradigma oral, quanto as suas presumíveis afecçóes na alma do ouvinte e do leitor.
\end{abstract}

${ }^{3}$ Repensar o estatuto tanto ontológico quanto deontológico do mito, objetivando recontá-lo, a fim de aplicá-lo a seus propósitos filosóficos, dotando-o de um sentido específico, constitui um dos procedimentos compositivos de Platáo na elaboração dos Diálogos, reiterando a perspectiva da hermenêutica cultual, pois, para o filósofo, a mitopoese não é considerada nem ancila da filosofia, tampouco cópia degradada da realidade, mero sucedâneo do paradigma, de modo que o mito se manifesta como possibilidade hermenêutica, chave da compreensão das implicaçóes ontológicas e gnosiológicas, porquanto a linguagem expressiva busca evidenciar pelo recurso à imagem, o que a linguagem descritiva não tem a função de captar. As pretensas lacunas e as antinomias na escritura platônica, reclamadas pelos partidários da leitura esoterista, como Hans Krämer e Konrad Gaiser, ao invés de denunciarem, pela ótica do formalismo lógico, as supostas incompletudes e inconsistências do sistema, revelam a consciência do filósofo mitólogo em relação aos limites do discurso declarativo. Os mitos genealógicos apresentados nos Diálogos, de acordo com a classificação proposta por Jean François Mattéi (MATTÉI, 1996, p. 138), são considerados (i) o mito da humanidade primitiva, no Protágoras, (ii) o mito dos filhos da terra, em República III e IV, (iii) o mito aristofânico dos homens primitivos e (iv) o do nascimento de Eros, ambos no Symposium, (v) o mito da idade do ouro e (vi) o do reino de Cronos, presentes no Politico, (vii) o mito de Theuth sobre a gênese da escrita e (viii) o mito das cigarras, descritos no Fedro, (ix) o mito da antiga Atenas e da Atlântid.a no Timeu e Crítias, assim como (x) todo o Timeu, por ser um discurso verossímil (logos eikòta) sobre a gênese do cosmo, ao passo que os mitos escatológicos presentes nos Diálogos se referem (i) ao mito do Julgamento final, no Górgias e também no Fedro, (ii) ao mito de Er, em República III, (iii) ao mito da atalagem alada, no Fedro, aos quais se pode associar (iv) o mito do Crítias, porque se trata não apenas da origem dos Atlantes, mas também de seu fim, narrando desde a fundação da ilha, por Poseidon, até sua completa corrupçáo, por Zeus. Tanto o mito do destino das almas quanto o mito escatológico de seu eterno ciclo palingenético das almas, expostos no Fédon, explicitam a relevância concedida por Platẫo à função epistemológica e ontológica da memória e aos cultos mnemosianos, cuja representação precípua se dará na imagem da psicagogia executada pelo cortejo divino, no Fedro. Projetando na mitopoese o preceito filosófico, com sua implicaçáo órfico-pitagórica, do perfeccionamento da alma pela metempsicose, o relato mítico da palingênese, propugnando a vida filósofa, correlata à vida desperta sábia, como télos da mýesis, retém o procedimento cultual do rito purificatório arcaico, em que "[...] a inspiraçáo órficopitagórica é, sobretudo, evidente no Fedro, no qual Platão trata da ascensão da alma do filósofo no espaço supraceleste, onde se contempla o verdadeiro, o real (tò alethés, tò òn óntos) e o intelecto (nô̂s), único piloto (kybernétes) da alma." (PUGLIESE CARRATELLI, 2003, p. 46). 
tanto estilísticos quanto imagéticos, sem o devido estatuto epistemológico concedido à exposição das ideias.

Conforma-se, no diálogo, uma atinada concepção de alma, coligindo seus aspectos mítico e racional, vinculada à sua capacidade cognitiva, proveniente da função epistêmica da memória e da reminiscência, imprescindíveis à aquisição das ideias e à superação da pluralidade fenomênica, tendo como escopo a unidade essencial ingênita e incorrupta. Proponho realizar uma interpretação do diálogo, preconizando uma relação dialética entre o discurso conceitual, examinado tanto na primeira quanto na segunda seção, e o discurso figurativo, exposto na terceira seção, pela qual viso a romper com a anacrônica separação moderna entre mito e racionalidade.

Por economia de exposição, circunscrevo a análise ao Fédon, visando a ressaltar o estatuto lógico, ontológico e epistemológico do que denomino alma remêmora, ou seja, a alma capaz da atividade da reminiscência, que, pelo raciocínio da causa, compreende as ideias. Contudo, é preciso proceder antes ao exame de que o aprendizado é anamnese (mathésis anámnesis) e, por consequência, da alma imortal, evidenciados no Mênon, mediante a lide entre Sócrates e o personagem epônimo a respeito do aspecto da virtude.

\section{MATHÉSIS ANÁMNESIS}

Em Mênon, Sócrates, a fim de demonstrar que o aprendizado é reminiscência, se baseia no relato de Píndaro, pois o poeta tebano declara que os sacerdotes e sacerdotisas professam ser a alma humana imortal (tèn psychèn tồ anthrópou athánaton), já que, quando advém o término da vida, a alma renasce, não sendo jamais corrompida (Men. $81 \mathrm{~b})$ e, tendo contemplado múltiplas coisas em vida e no Hades, não há nada que a alma não tenha outrora aprendido. ${ }^{4}$

\footnotetext{
${ }^{4}$ Conforme Bernabé, os versos pindáricos citados por Sócrates exprimem uma teoria da alma que Platão estava disposto a aceitar, pois lê em "Píndaro um orfismo filtrado, moralizado, distante de suas variantes mais grosseiras.” (BERNABÉ, 2011, p. 161). Para Pugliese-Carratelli, em seu estudo sobre as lâminas de ouro órficas, das quais se destaca, para melhor compreensão da dívida platônica com o orfismo, a lâmina de Hiponion, "[...] sem dúvida as teorias pitagóricas da mnéme e as doutrinas órficas vizinhas correlatas à função da deusa Mnemósine estavam presentes quando Platão começou a elaborar sua doutrina da anámnesis, prelúdio à sua teoria das ideias." (PUGLIESE-CARRATELLI, 2003, p. 46). A reminiscência (anámnesis) permite à alma remêmora a concatenação das opiniốes verdadeiras, a fim de que se tornem ciências e se tornem estáveis, de sorte que a virtude, porque não seja ensinável, é correlata não à ciência, ensinável, mas sim à boa opinião, própria àqueles que regem corretamente as cidades, aos adivinhos divinos e aos vaticinadores, tornando-se meritório denominá-
} 
O procurar (tò zeteîn) e o aprender (tò manthánein) são, em seu amplexo epistêmico, para Sócrates, uma rememoração (anámnesis) (Men. 81 d). A tese de que o conhecimento é reminiscência e de que a virtude não é ensinável, pois é adveniente da rememoração realizada pela alma, revela uma etapa original na elaboração do diálogo, relativa à teoria da imortalidade da alma, de sorte que saber não é aprender, mas rememorar opinióes verdadeiras (aletheîs dóxai) dormentes, as quais, despertadas pelo constante questionamento, se tornam ciências (epistêmai) (PLATÁO, Men. 86 a). As ciências advêm da premência do não esquecimento, portanto, da gênese da reminiscência, pela qual a alma desvela a realidade. A apreciação da atividade mnemônica acentua o caráter ingênito e não ensinável do conhecimento, ao passo que a geração do esquecimento se refere ao êxodo da memória, ao não saber, à incapacidade de desvelar o real. A natureza não empírica do aprendizado é propugnada pela teoria da alma imortal e pelo consequente poder remêmoro.

Se a verdade dos entes (alétheia tôn ónton) ou, então, o não esquecimento dos entes, das coisas que são, reside sempre em nossa alma, a alma é concebida imortal, pois, se não conhecemos algo num presente momento, porque não o rememoramos, torna-se preciso, encorajando-se, se empenhar em procurálo e rememorá-lo (epicheireîn zeteîn kaì anamimnésthai) (PLATÃO, Men. 86b), zetésis realizada pelo emprego do processo de refutação, do élenchos, permitindo ao interlocutor, o qual tem a presunção do conhecimento, purificar-se dos falsos saberes. Segundo Monique Dixsaut, a anamnese provém do reconhecimento do não saber, pelo qual a alma almeja se apossar do saber e do aprendizado. $\mathrm{O}$ esquecimento não significa "[...] a perda de um conteúdo, pois o esquecido não é a soma de conhecimentos, mas sim o poder da alma de apreender a verdade do ser." (DIXSAUT, 2003, p. 114).

Do uso do método de hipóteses, no Mênon, ao emprego do método de divisão por formas, no Filebo, se verifica, ao longo dos Diálogos, a relevância epistemológica da memória e da reminiscência na configuração sensu stricto

los divinos, haja vista que, não possuindo nem o intelecto nem a ciência, efetuam, pelo emprego da reta opiniáo, coisas tidas por valorosas. A boa opinião, eudoxía, partilhada tanto por cidadáos participantes do âmbito político quanto pelos vaticinadores e adivinhos divinos, evidencia o percuciente liame, atestado no pensamento platônico, entre o horizonte político e o horizonte cultual, entre o mítico e o lógico. A virtude não é, pelo raciocínio socrático, nem por natureza nem ensinável, mas concedida como parcela divina sem intelecto aos homens bons, àqueles que regem corretamente as cidades, aos adivinhos divinos e aos vaticinadores (Men. 100 a). Se houvesse, entre os cidadãos, alguém capaz de tornar outrem cidadáo, esse seria entre os viventes, no que se refere à virtude, uma coisa verdadeira em relaçấo às sombras (Men. 100a). A virtude, auxiliada pela reta opiniáo e pela ciência, tornaria os homens despertos, afastando-os da ignorância e da nescidade. 
da dialética, em Platão. A compreensão de que o conhecimento é anamnese impóe a reflexão sobre os limites da aplicação das modernas categorias lógicas de pensamento no estilo inquisitório socrático, haja vista que o recurso à memória permite a Sócrates realizar a síntese intelectual entre o discurso mítico e o discurso filosófico. O processo dialético se revela imbricado com o saber anamnésico, de modo que Mênon prenuncia o nexo precípuo à formação do pensamento filosófico. Mnemósine, na tradição hesiódica cosmogônica, pondera e arbitra entre o ocultamento do Oblívio, âmbito meôntico, e a fulgência da Presença, território ôntico celeste.

O entendimento das funções da potestade olímpica explicita a herança platônica da tradição teogônica, já que a função epistemológica da memória, análoga à função simbólica da deusa, é propiciar a anamnese. Configuramse no exercício socrático da bela morte, desenvolvido no Fédon, quatro argumentos correlatos (i) à afirmação do aprendizado como reminiscência (mathésis anámnesis); (ii) à evidência da imortalidade da alma; (iii) à suprema congeneridade entre ideias e essências e, por fim, (iv) à afinidade ontológica entre a alma e as ideias.

O diálogo entre Símias e Cebes, apresentados como pertencentes ao círculo de Filolau ${ }^{5}$, e Sócrates, sobre a natureza da alma, no Fédon, realizado prestes à execução desse filósofo, relatado pelo personagem epônimo a Equécrates, explicita a parênese da filosofia e sua preparação para a morte. Sócrates não se concebe mitólogo, privilegiando os discursos ante os mitos, interpretando-os à luz das convicçóes, mas contará sobre a jornada purificatória a ser principiada no poente e que o conduzirá do reino umbrático, relatado nos mitos escatológicos, à morada súpera em que a alma se revela congênere à sabedoria. O filósofo mitólogo do rito purificador, da jornada ao ser puro, opóe-se ao simples fabulista, ao metrificador dos ditames esópicos. Ressalta-se a oposição entre o privilegiado filósofo e o mitólogo popular, à medida que o

\footnotetext{
5 Luc Brisson reivindica a aplicação de um método histórico prudente e lúcido, para elucidar os hipotéticos nexos entre Pitágoras, o pitagorismo e Platâo, firmados pela doxografia aristotélica, sem o qual a especulação platônica da palingenesia se revela um decalque pitagórico, tratandose de demonstrar como Platáo interpreta a tradiçâao pitagórica. Brisson indaga se Símias e Cebes, interlocutores de Sócrates e personagens do Fédon, são, de fato, discípulos do pitagórico Filolau de Crotona - indagação realizada por uma insuficiência mesma de dados precisos fidedignos sobre o Filolau referido no diálogo, uma vez que "[...] é impossível saber de onde Filolau é originário, quando viveu, se era coetâneo de Pitágoras ou de Empédocles, se era de Sócrates, porque e como esteve em Tebas." (BRISSON, 2002, p. 30). Carl Huffman (HUFFMAN, 1999, p. 16) anui, contrário à dúvida enunciada por Luc Brisson, ser evidente que o Filolau do diálogo é, de fato, um membro do pitagorismo do quinto século e não apenas um mero personagem homônimo.
} 
cultor da filosofia se revela apaixonado pela natureza divina, aspirando, pela sabedoria numinosa, ao convívio dos deuses benfazejos.

A apologia socrática da morte evidencia a aspiração filósofa à relação convival com o divino e com o imortal, de modo que a teoria da palingênese apresenta um forte componente ontológico, permitindo a Platáo interpretar a tradição religiosa na perspectiva epistemológica. ${ }^{6}$ Se o filósofo é tido por amado dos deuses, urge expor por que a supressão da vida lhe causa júbilo, em face do ditame de Cebes, para quem a maior graça consiste em viver plenamente sob a tutela divina, rejeitando a morte, já que se deve provar não apenas a excelência do rito purificatório, no qual a alma se aparta do corpo, libertando-se, mas a congeneridade entre o filósofo e o divino.

A filosofia se revela por causa da anuência da alma imortal, como um saber propriamente anamnésico, desvelando as ideias sempiternas, relativo à concepção de que o aprendizado é anamnese. A concepção de que os mortais são uma parcela do que é próprio à divindade (Fed. 62b), revelando ser nossa melhor tutora, evidencia o nexo entre os horizontes político e cultual, pois os homens providos de sabedoria e de intelecto possuem uma natureza congênere ao divino. A suprema congeneridade permite a Sócrates o encômio da preparação para a morte, pois é considerada a separação da alma do corpo. O filósofo, libertando a alma da comunidade com o corpo (tèn psychèn apò tês tôu sómatos koinonías), diferencia-se dos outros homens (PLATÃO, Fed. 64 e), sendo congênere ao divino. O corpo é impedimento à própria aquisição de sabedoria (autèn tèn tês phronéseos ktêsin) (PLATÃO, Fed. 65a), de sorte que as sensaçôes corpóreas não são nem exatas nem evidentes. Se a alma se empenha em escrutinar algo com o auxílio do corpo (metà tôे sómatos), é por ele ludibriada. A alma, apartada do corpo, não tendo com ele nem comunidade nem contato, concentrando-se em si mesma, sem a ajuda de sensaçóes corpóreas, raciocina melhor e aspira ao ser (orégetai toû óntos) (PLATÃO, Fed. 65c).

\footnotetext{
${ }^{6}$ Brisson afirma ser comum considerar a transmigração das almas como um dogma do Orfismo e do Pitagorismo, da chamada tradição órfico-pitagórica, tendo Platão o assimilado. A transmigração das almas constitui o fundamento mitopoético da teoria da reminiscência e da alma remêmora, conditio sine quae non da teoria das ideias, implicando a noçáo de forma inteligível separada, podendo ser contemplada pela alma purificada do corpo. "Pindare, Empédocle, Hérodote et Platon connaissaient l'existence de mouvements religieux qui soutenaient la doctrine de la transmigration. Il semble que ces mouvements eurent une influence sur le Pythagorisme et sur le Orphisme. Dans cette perspective la question de savoir lequel, du Pythagorisme ou de l'Orphisme, a pu influencer l'autre n'a pas de sens." (BRISSON, 2002, p. 42).
} 
A alma filósofa almeja, recusando o corpo, agregar-se em si mesma, compreendendo, pelo raciocínio e não pela sensação, os entes em si, como o justo em si (díkaion autò), o belo e o bom em si (kalòn kaì agathòn). A apreensão do verdadeiro, do justo, do belo e do bom em si se realiza sem a miscibilidade corpórea, sem o apoio da visáo e de outros sentidos, e a pureza advém não do auxílio das sensaçôes, mas do emprego do pensamento em si e imiscido (autê kath'autèn eilikrineî tê dianoía), empenhando-se na caça dos entes imiscidos e em si (autò kath'autò hékaston eilikrinès tôn ónton) (PLATÃO, Fed. 66a). A alma filósofa, arrefecendo, pela sabedoria, o nexo e a comunidade com o corpo, esforça-se para atingir, por meio da cuidadosa purificaçáo, o ser puro. A purificação (kathársis) consiste em separar, pelo exercício para a morte, a alma do corpo (tò chorizein apò toû sómatos tèn psychèn), habituando-se a se condensar e se agregar em si mesma (PLATÁO, Fed. 67 c), de modo que a morte é a liberação e separação da alma do corpo (lýsis kaì chorismòs psychês apò sómatos) (PLATÃO, Fed. $67 \mathrm{~d}$ ).

A vida sábia se constitui na prevalência da alma racional para comandar o corpo e seus múltiplos padecimentos. O filósofo, epopta e iniciado no rito purificatório, habita post mortem o Hades, junto com os deuses. Se o verdadeiro conhecimento surge, pelo emprego da meléte thanátou, da concentração da alma em si mesma, do pensamento sem mistura com o apoio do raciocínio, é preciso, destarte, provar a subsistência da alma depois de sua separação do corpo. Se, no Mênon, se afere que o aprendizado é anamnese (mathésis anámnesis) efetuada pela alma remêmora ${ }^{7}$, é necessário atestar, no Fédon, tanto a imortalidade da alma, a natureza de suas propriedades, quanto sua função epistêmica, empregando o método por hipóteses, o qual, acompanhado de raciocínio e exatidão, possibilita a compreensão da imortalidade da alma e de

\footnotetext{
7 Gregory Vlastos ressalta, no argumento da alma remêmora, exposto no diálogo Mênon, a transformação de um Sócrates moralista, apresentado nos diálogos iniciais, para um Sócrates metafísico, presente nos diálogos intermediários, havendo a transição dos diálogos iniciais elênticos para os diálogos intermediários maiêuticos: "In the Socrates of this passage Plato has already taken a giant step, the doctrine of recollection, in transforming the moralist of the earlier dialogues into the metaphysician of the middle ones. The interrogation is laid on to suport that doctrine, to help Meno to recollect it." (VLASTOS, 1994, p. 5). Segundo Dixsaut, a teoria da alma remêmora retoma elementos mitopoéticos. "Il reste bien encore quelque chose de mythique: la representation d'un savoir total que l'âme aurait possédé et perdu. Ce qui est mythique est l'idée meme d'un savoir total." (DIXSAUT, 2003, p. 116). Jean Pierre Vernant, em seu conspícuo estudo sobre os aspectos míticos da memória, correlatos à deusa Mnemósine, de par com a filologia e a arqueologia, afirma que a anamnese em Platão não se refere mais ao passado primordial nem a existências anteriores, constituindo-se como princípio epistemológico, tendo "[...] como objeto verdades cujo conjunto constitui o real. Mnemósine, força sobrenatural, interiorizou-se para se tornar no homem a própria faculdade do conhecer." (VERNANT, 1990, p.161).
} 
seu parentesco com as ideias, causadoras da geração, pois ambas, alma e ideia, participam do divino e incorrupto.

A palingênese remete a pari ratione à comprovação do saber anamnésico, de que o aprendizado é anamnese (mathésis anámnesis) (PLATÃO, Fed. 72e) ${ }^{8}$, sendo preciso que tivéssemos antes aprendido o que, em dado momento, rememoramos (PLATÃO, Fed.72e). A anamnese seria impossível, se a alma não existisse antes de devir na forma humana, parecendo ser a alma algo imortal (athánaton ti psychè) (PLATÃO, Fed. 73a). Se rememoramos algo, é necessário que já o tivéssemos conhecido, de forma que, quando surge a ciência, é anamnese (epistéme paragígnetai anámnesin) (PLATÃO, Fed. 73c). A ciência, associada à anamnese, é apreendida pela alma remêmora, pois, se contemplamos, se ouvimos ou temos alguma outra sensação de algo, não apenas o reconhecemos, mas temos o pensamento de algum outro, pois o ato de rememorar consiste na apreensão da ideia de algo.

A mútua relação entre os entes sensíveis, entre o amado e a lira, entre Símias e Cebes, propicia aduzir as supostas semelhanças e dessemelhanças, revelando sensaçôes antes experimentadas. A aferição sensível de presumíveis igualdades ou desigualdades entre os entes visíveis provém da anamnese do igual em si e do desigual em si, contemplados pela alma rememora, em vidas primevas, sendo preciso, previamente ao tempo, prever, conhecer, pela atividade da alma o igual (proeidénai tò íson), de modo que, contemplando, primeiramente, as coisas iguais, pensamos que todas essas almejam serem semelhantes ao igual em si, sendo-lhe, decerto, inferiores (Fed. 75a).

\section{A SEMÂNTICA DA INVISIBILIDADE NA SEGUNDA NAVEGAÇÃO}

A epistemologia, adveniente da comprovação do nexo iniludível entre a alma e as ideias, é tributária da (i) tese da alma imortal remêmora e do (ii) saber anamnésico, de modo que a epistéme se revela como conhecimento pré-natal

8 Vlastos enfatiza que a concepçâo do aprendizado anamnésico nấo remonta aparentemente ao pitagorismo, pois se atesta nesse apenas a doutrina da transmigração, não havendo um nexo evidente com a teoria da reminiscência. Se o pitagorismo defende a imortalidade da alma e a metempsicose, não se pode anuir o saber rememorativo, sendo tópico essencialmente do pensamento platônico. "This doctrine, the only one that would deserve mention in a history of the theory of knowledge, let alone mention as a milestone in this theory, is the product of Plato's genius and of his alone." (VLASTOS, 1971, p. 101). Alberto Bernabé corrobora a posição de Vlastos: "O fato é que Platão aceita a ideia órfica de que a alma é imortal, o que supóe que seja algo separado do corpo que, por sua vez, é mortal. $\mathrm{E}$, neste caso, o faz porque lhe serve adequadamente para sustentar a teoria da reminiscência, que não é, de modo algum órfica." (BERNABÉ, 2011, p. 161). 
adquirido pela alma, enquanto o esquecimento (léthen) é a perda da ciência (epistémes apobolén) (PLATÃO, Fed. 75 d). Se se supóe que, ao nascermos, perdemos o saber pré-natal e, a fim de apreendê-lo, empregamos os sentidos, o que se denomina aprender (manthánein) nada mais é do que apreender uma ciência particular (oikeian epistémen analambánein) (Fed. 75e). A percepção de algo pela visão, pelo ouvido ou por outro sentido possibilita pensar em outro que havíamos esquecido e do qual aquele mantém afinidade, sem lhe ser, porém, semelhante (PLATÃO, Fed.76a). O reconhecimento de determinado ente não se realiza pela experiência sensível imediata, porém, a empiria nos propicia a anamnese do olvido, de sorte que não há o opróbrio da sensação, mas a anuência de sua subordinação epistemológica à reminiscência. Se há o belo, o bom e todas as essências congêneres, reportando-lhes todas as coisas que nascem dos sentidos, então a alma existiria anterior às nossas sensaçóes, devendo-se evidenciar a afinidade ontológica entre a alma e as essências, à medida que ambas existem previamente aos sentidos e às coisas percebidas.

A alma e as essências são, de um lado, mediante suas naturezas congêneres, realidades idênticas a si mesmas (aei katà tautà), imutáveis (hosaútos échei) e incompósitas (tà axýntheta); as sensaçôes e as coisas percebidas, de outro, não são idênticas a si mesmas (medépote katà tautá), sendo mutáveis (tà állot'állos) e compósitas (sýntheta) (PLATÂO, Fed. 78 c), de maneira que essas são compreendidas pelos sentidos (tâ̂s aisthésesin), enquanto aquelas, pelo raciocínio do pensamento (tô tês dianoías logismô), havendo duas espécies de entes: de um lado, o invisível (tò mèn aidès) e imutável e, de outro, o visível ( $t \grave{o}$ dè horatòn) e mutável; este se reporta ao corpo, aquele, à alma (Fed. 79 a). O corpo compósito possui mais semelhança e mais congeneridade (homoióteron kaì syngenésteron) à espécie visível, enquanto a alma incompósita é mais semelhante e congenérica à espécie invisível.

Segundo David Bostock ${ }^{9}$, o argumento da congeneridade entre, de um lado, o incorpóreo, a alma, o pensamento e as essências e, de outro, o

\footnotetext{
9 Bostock elenca quatro argumentos fundamentais no Fédon. "There are essentialy four arguments, namely (i) the cyclical argument $(69 \mathrm{e} / 72 \mathrm{~d})$, (ii) the recollection argument $(72 \mathrm{e} / 77 \mathrm{~d})$, (iii) the affinity argument (77e/80b) and (iv) the final argument (95e/106e). But between the third and the fourth argument there comes an interlude." (BOSTOCK, 1999, p. 422). Fabián Mié, por sua vez, considera haver três provas ontológicas sobre a imortalidade da alma no Fédon, relativas à (i) equiparação entre aprendizagem e reminiscência, (ii) afinidade ontológica entre a alma e os objetos concebidos indissolvíveis e imperecíveis do conhecimento, (iii) causalidade da ideia em relação à gênese e corrupção. "En la última demostración de la inmortalidad del alma que desarrolla el Fédon, Sócrates introduce la hipótesis de las ideas de manera más decidida de lo que lo había hecho en el ofrecimiento anterior de uma prueba baseada en la equiparación entre aprendizage y rememoración o, a continuación de ello,
} 
corpóreo, as sensaçóes e as coisas sensíveis com suas formas epônimas, subsequente aos argumentos da palingenesia e da anamnese, precede e prepara o argumento da causalidade necessária, estratégica para a teoria das Formas, já que a espécie invisível se manifestou ser o princípio hegemônico e comando da espécie visível. $\mathrm{O}$ argumento da causalidade necessária estabelece o princípio ontológico da hipótese das ideias, necessária à segunda navegação.

Sócrates explicita a Cebes o exame da causa (epi tèn tês aitías zétesin), na segunda navegação (tòn deúteron ploûn) (PLATÃO, Fed 99 d), porquanto temera que sua alma se tornasse inteiramente cega, se contemplasse as coisas apenas com os olhos, parecendo-lhe ser preciso refugiar-se em raciocínios (eis toùs lógous) e examinar a verdade dos entes (tôn ónton tèn alétheian) (PLATÃO, Fed. 99e), de sorte que, tendo instituído como fundamento o raciocínio (hypothémenos lógon $)^{10}$ que aduz o mais sólido, julga ser verdadeiro aquilo que lhe for consoante, concernente à causa e todas as outras coisas, e não verdadeiro o que não lhe for consoante (PLATÃO, Fed.100a). A segunda navegação supera a compreensão fenomênica, realizada pelos pensadores naturalistas, examinando a causa, não na espécie visível, mas na espécie invisível, admitindo a hipótese de duas espécies de entes, de um lado, a sensível, fenomênica, e, de outro, a inteligível, metafenomênica.

O reconhecimento socrático de que Anaxágoras não considerou retamente o intelecto como o causador de todas as coisas lhe póe a premência da segunda navegação (deúteros ploûs), pela qual intenta superar as concepções de seus predecessores, os investigadores da natureza. Sócrates se esforça para explicar a Cebes a forma da causa (epideixasthai tês aitías tò eîdos) que

en la segunda prueba, demostrando que el alma, em razón de su afinidade ontológica con lo que son sus objetos de conocimiento, no pertenece al tipo de entidades que se descompone o disuelve. Pero en la terceira prueba las ideas son postuladas como las únicas causas que pueden explicar lo que algo es cuando eso se genera o se corrompe." (MIÉ, 2004, p. 31).

${ }^{10}$ Charles Kahn aduz que o Mênon é o primeiro texto do corpus platônico, o qual, ao empregar o termo hypothesis, visa a diferenciar com acurácia e claramente a verdade das premissas e a validade da inferência, favorecendo assim pensar a epistemologia de par com a ontologia: "The early dialogues also employ the term hypothesis for the position or thesis that the interlocutor seeks to defend. But the Meno is the first text, to my knowledge, to distinguish sharply and clearly between the truth of the premiss and the validity of the inference." (KAHN, 1996, p. 309). Sócrates solicita o consentimento de Mênon para que, ao modo dos geômetras, em função do emprego de hipóteses (ex hypothéseos), se examine (skopeîsthai) se a virtude é ensinável (didaktón) (Men. 86e). Pela expressão a partir da hipótese (tò ex hypothéseos), Sócrates se refere à forma como os geômetras frequentemente examinam (skopoûntai) (Men. 86e). O dialético, definido stricto sensu pela posse e presença da alma remêmora, utiliza as hipóteses para obter a definição, almejando o raciocínio da causa. Sócrates emprega as hipóteses, indagando se a virtude é ou não é ensinável, se é ou não ciência, rejeitando a agonística baseada em meras refutaçōes e se apropriando do método de hipóteses adotado pelos geômetras. 
pesquisara, estabelecendo como hipótese haver um belo em si (ti kalòn autò kath'autò), um bom, um grande e todos outros (PLATÃO, Fed 100b).

Para assegurar o encômio socrático da imortalidade da alma, a lide propôs três argumentos correlatos (i) à palingenesia, (ii) à anamnese e (iii) à afinidade ontológica entre a alma e as ideias, a fim de provar as prioridades ontológica e epistemológica da alma em relação à corporeidade. Se Cebes aceitar essas formulaçóes, Sócrates lhe propóe mostrar e lhe explicar a causa da imortalidade da alma, pois se consentiu haver a congeneridade entre a alma incorpórea e as ideias imateriais. Se há outro belo que não o belo em si (autò tò kalón), é porque aquele belo participa do belo em si (metéchei tôu kalô̂), porque o que torna algo belo seria ou a presença (parousía) ou a comunidade (koinonía) com o belo (PLATÃO, Fed. 100 d).

Assim, é necessário que cada coisa participe da essência particular (tês idías ousias) daquilo do qual ela participa, já que as coisas belas se tornam belas, porque participam do belo em si. As coisas que participam do belo recebem sua própria denominação, sendo seu epônimo. O contrário em si, não sendo forma epônima, porém,s sendo forma em si, autò kath'autó, relativa à forma inteligível, não pode jamais nem se alterar nem se corromper, nem devir nem se dissipar, porquanto se mantém sempre idêntico a si próprio, ingênito e incorrupto, podendo manter relaçóes intereidéticas com outros contrários em si, já que a alma, depurando-se do sensível transiente, e pelo processo epistemológico de rememoração, compreende as possíveis relaçóes de identidade e de alteridade entre as próprias ideias transcendentes.

Da adesão incondicional à ideia ontológica da imortalidade, a alma filósofa, por seu poder e sua sabedoria e tendo o dom divinatório apolíneo, aspira ao divin,o assim como ao ser real inteligível. O nexo e a comunidade da alma com o corpo são pensados pelo intermédio da lógica da mútua relaçáo entre contrários, entendidos como termos antitéticos e como opostos complementares. Se se atribui ao Fédon, de acordo com a preceptiva filosófica, a instituição da ontologia canônica do platonismo, fundamentando em uma metafísica dos dois mundos a sua teoria das Formas, descura-se da relação de inclusão e exclusão entre as próprias Formas efetuada pela alma, promovendo a comunidade intereidética, tese central da ontologia desenvolvida nos diálogos finais, particularmente no Sofista, onde o contrário não é considerado como simples privação, mas como exato oposto complementar, acarretando a ulterior relevância no platonismo tardio do escrutínio da natureza não apenas do ser, contudo, também do gênero do não ser, descritas na teoria da comunidade dos 
gêneros supremos do Sofista, de sorte que não há a recusa nos diálogos finais da ontologia propugnada nos diálogos intermediários. ${ }^{11}$

\section{Propor a segunda navegação e o refúgio nos lógoi não obsta Sócrates a} recorrer ao raciocínio dos coincidentia opositorum, relacionando-o no percurso lógico à relação entre forma epônima e forma inteligível. A noção, portanto, de que as coisas sensíveis participam de suas respectivas ideias, assim como das ideias que lhe são contrárias, configura para o pensamento platônico a unidade enantiológica entre gênese e essência, entre ideia e imagem, enfim, entre o ser e o não ser, como será ulteriormente determinada, no Sofista, pela referência à comunidade dos cinco gêneros supremos, em que o sensível participa não somente de seu respectivo inteligível, de sua ideia correlata, mas também do inteligível que lhe é contraditório, conformando uma complexa estrutura de unidade e multiplicidade, rompendo com a presumível lógica da não contradição, cara ao pensamento aristotélico e à sua herança interpretativa, cuja leitura da ontologia platônica privilegia a tese do chóriston, ou seja, dos universais separados e a tese do terceiro homem ${ }^{12}$, de maneira que a compreensão das relaçôes tanto intereidéticas, no plano inteligível, quanto intrafenomênicas, no plano sensível, depende da abordagem da teoria da alma remêmora, associada à tese da imortalidade da alma e, consequentemente, do argumento epistemológico da reminiscência. ${ }^{13}$

\footnotetext{
${ }^{11}$ Segundo Fabián Mié, a conclusāo sobre a imortalidade da alma se apoia nas inclusões e exclusôes eidéticas correspondentes à determinação própria dessa entidade que é a alma: "El Fedón cuenta, entonces, con la posibilidad de articular la uniformidade del eidos em relaciones ideales, lo cual significa que la unidad de cada idea envuelve uma multiplicidad y que esa estrutura de unidad y multiplicidad, que constituye la estrutura de la determinación e identidad de cada forma, está implicada en el contenido especifico de cada idea. La conexión y exclusión (implicación y no implicación) entre las ideas es el fundamento de la episteme en su diferencia respecto de la doxa, según lo marca el Ménon (98 a) con la fórmula aitías logismô." (MIÉ, 2004, p. 42).

${ }^{12} \mathrm{~A}$ interpretação aristotélica do pensamento platônico é sujeitada às próprias categorias metafísicas do Estagirita. Charles H.Kahn sustenta que "Aristóteles não se interessa em reconstituir a dialética histórica do quinto século, compreendida como uma resposta à ontologia eleata. Aristóteles concebe seus predecessores como interlocutores em uma discussão fora do tempo." (KAHN, 2001, p. 214). Alguns autores conspícuos, como Harold Cherniss, Luc Brisson e Monique Dixsaut, corroboram a premissa de Charles Kahn, para quem o testemunho aristotélico é, antes, a interpretação de seus predecessores mediante as suas categorias de pensamento, do que a reconstituição fidedigna da doutrina daqueles.

${ }^{13}$ Charles Kahn evidencia como tanto a teoria da reminiscência quanto a tese da imortalidade da alma fundamentam a ontologia das Formas, năo podendo ser pensadas como meras consequências lógicas de que as Formas existem. "The doctrine of recollection and the immortality of soul are not presented as logical consequences of the assertion that the Forms exist. The epistemology of recollection and the concept of the eternal psyche have their place in a larger philosophical scheme of things, whose most fundamental component is the ontology of Forms." (KAHN, 1996, p. 317). V. Dixsaut
} 
As relações de oposição complementar entre (i) os próprios fenômenos, (ii) entre os fenômenos e suas ideias e (iii) entre as próprias ideias são atestadas na relação antitética entre a alma invisível e o corpo visível, reportada à relação entre o imortal e o mortal, já que o humano precisa conter em si não apenas sua respectiva ideia, a qual lhe confere existência, a do mortal em si, mas também sua ideia contrária, a do imortal em si, reportando à lógica de oposição complementar, remissiva à reflexão mitopoética, unificando, pelo raciocínio dialético, os pares de opostos, correlatos ao mortal em si e ao imortal em si. A atinada percepção dessas oposições permite aferir o princípio de diacosmese, cara ao pensamento eleata, permeando intermitentemente o processo metabólico de geração e do eterno ciclo das compensaçôes, adverso à mera alternância indistinta dos contrários, propugnada pela antilogia erística, que não diferenciando, adversa à ciência dialética, forma epônima e forma inteligível, confunde, no plano fenomênico no qual se inscreve a pólis, o dessemelhante com o semelhante, o mesmo com o outro, e, no plano deontológico, fundamental para o personagem socrático, contraexemplo do erístico refutador, o vicioso com o virtuoso, o justo com o injusto.

A alma, por ser imperceptível, invisível e antitética ao corpo, é congênere às ideias incorpóreas, contendo em si sua ideia antitética. Os belos visíveis existem por participação na ideia invisível do belo em si, sendo-lhes seu causador, princípio de causalidade, pois, assim como há açóes justas pela participação na ideia do justo em si, sendo-lhes também sua causa, as coisas sensíveis devem ser apreendidas pelo raciocínio, não por meio de suas relaçóes recíprocas perceptíveis imediatas, já que turvam o reto pensar, mas por suas ideias correlatas, salientando a relação entre imagem visível e ideia invisível, entre aparência e seu modelo. ${ }^{14}$ Se se aceita a pré-existência da alma, deve-se

(DIXSAUT, 2003, p.115: "L'interprétation de la réminiscence en terme d'innéité des Formes introduit une hypothèse dont Platon fait l'économie: les Formes sont posées par l'élan de l'âme quand elle se ressouvient de sa puissance de saisir ce qui est véritablement, par elle seule et sans le secours des sens."

${ }^{14}$ A participação dos entes sensíveis em suas formas inteligíveis nos reporta, sempre, à relação entre as formas antitéticas, visível e invisível, imagem e modelo, não ser e ser, reiterando a lógica de oposição e complementaridade em face da lógica apodítica, pois tanto a alma imortal invisível mantém uma relaçấo enantiológica com o corpo gênito visível quanto o ser imiscido com o nấo ser absoluto, de maneira que o ato real de conhecimento consiste, no pensamento mítico, na hierogamia entre as potestades olímpias da memória e as potestades ctônias do esquecimento. A leitura e a interpretação dos Diálogos demonstram, portanto, a constituiçáo de uma hermenêutica platônica do real, que chamo de hermenêutica cultual, e dos possíveis níveis de visibilidade e invisibilidade, expostos em seus mitos genealógicos e escatológicos, de modo que, a partir da minudente análise da existência fenomenal, Platão compóe sua ontologia. A assimilação refletida da oposição cultual entre os Deuses ctônios e os Deuses olímpios revelou-se paulatina na mentalidade arcaica e clássica, registrada tanto na relação entre o denso e o raro no poema de Parmênides quanto na oposiçăo platônica entre a noite escura e a luz 
admitir sua permanência depois da morte física, porquanto participa da ideia do imortal, subsistindo nela a educação e a nutrição, recebidas em seu liame com o sensível.

À tese da imortalidade da alma sucede a de sua indestrutibilidade, porque, tendo sido considerada primeiramente imortal (athánaton), não é submetida à geração, tampouco à corrupção, de modo que, sendo imortal, é a pari ratione indestrutível (anólethron) (Fed. 106e), subsistindo no Hades umbrático. A alma, purificada do nexo corpóreo, é conduzida, de acordo com o mito escatológico do destino das almas, para o julgamento pela mesma divindade numinosa que outrora a teria guiado, na comunidade com o corpo, de sorte que o deus se manifesta como nume, se devidamente compreendido por sua relação com um destino particular, de uma coletividade ou de um mortal, por ele regido, tal como é preconizado por Sócrates.

A alma filósofa, amante do verdadeiro, do ser e congênere às ideias, tem a sabedoria numinosa como hegemônica, pela qual pode participar do ser puro imiscido, libertando-se das cadeias corpóreas relativas às afecçóes irascíveis, aos prazeres e dores ilimitados, aludidos por Sócrates, no proêmio de sua exposição. Assim, somente o filósofo desperta e se liberta da dominação que esse sonho, correlato ao mundo da vida, exerce sobre nós, e despertar desse sonho, assim como desse torpor, é precisamente desfazer-se de hipóteses, nas quais a interpretação do mundo é sedimentada e donde a nossa linguagem é tributária. Dessa constatação de que o périplo rumo ao ser real exige o descensus ad inferus, Platão erige de par com a mitopoese sua original teoria do conhecimento, cuja compreensão, principalmente a relativa à dimensão noética, escapa dos parâmetros impostos pela lógica apodítica.

\section{A SEMÂNTICA DA VISIBILIDADE E O MITO ESCATOLÓGICO}

A segunda navegação, preconizando o princípio da causalidade necessária, condição de inteligibilidade à realidade fenomênica, afere o reconhecimento socrático da hermenêutica dos cultos órficos, uma vez que as ideias são concebidas, por esse princípio, depuradas do elemento sensível, sendo congêneres à alma imortal. Enunciando em linguagem expressiva a condição libertária do filósofo, inserto na vida heroica, Sócrates, posicionando-

diurnal, entre o corpo e a alma, entre o ser e o não ser, territórios ôntico e meôntico, de sorte que, para Jean François Máttei, “[...] as práticas dos cultos ctônios e olímpios na cultura grega se contrapóem à orientação celeste dos sacrifícios destes a orientação terrenta daqueles." (MÁTTEI, 1996, p. 109). 
se como um reconhecido mystés, repropóe o ditame órfico da prevalência da vida incorpórea em relação à existência terrena, de modo que o elogio socrático da alma purificada propugna, pela experiência do sagrado, o parentesco entre o filósofo e o divino e a consequente participação da alma filósofa e remêmora nas ideias sempiternas. A hipótese das ideias, escrutinada na segunda navegação do Fédon, explicita a condição de sempiternidade da alma, porquanto se reconhece sua afinidade ontológica, pela teoria da anamnese, com as ideias, e pela anuência de que o aprendizado é reminiscência.

O mito escatológico do destino das almas explicita, portanto, as açóes necessárias para que o homem participe, em vida, da virtude e da sabedoria (aretês kai phronèseos) (Fed. 114c), pois belo é, para Sócrates, o prêmio, e magnífica é a expectação se regermos a nossa vida por esse mito primígeno. A récita socrática, pertinaz em seu encômio à sabedoria, supera a mera mitologia popular ou o simples exercício de fabulação, porque, hineando o exercício para a morte, a tanatomelète, Sócrates evidencia uma nova compreensão da função intelectiva da alma humana, superando as descriçóes homéricas e refinando as concepçóes arcaicas pré-socráticas, atestadas particularmente na filosofia jônica, em Heráclito de Éfeso, sobre a alma, e na filosofia itálica, no que concerne à palingenesia. Não se deve, pondera Sócrates, ao homem dotado de intelecto, sustentar firmemente a veracidade do relato mítico, mas belo é o risco, se se supóe a imortalidade da alma e a palingenesia, porque tais suposiçóes produzirão o encantamento, próprio ao éthos filosófico, demonstrando o poder da mitopoese, se empregada tendo em vista uma ortologia da imagem.

A narrativa mítica escatológica do destino final das almas reitera os elementos deontológicos necessários à constituição da vida justa feliz, tema central da ética grega antiga, de forma que o reconhecimento socrático do mito escatológico das almas, ratificada sua natureza não verdadeira, porém, verossímil do mito, um lògos eikóta, demonstra o equívoco de se pensar uma relação antitética entre o mito e a filosofia ou, entáo, a prevalência desta em relação àquele. A prédica mítica nos instrui a reger a vida em concordância com a temperança, sabedoria e justiça, verdade e magnanimidade, critérios designados ulteriormente no Filebo, sobre a vida feliz (bios eudaimon), como critérios propriamente dianoéticos, indicando nosso fabuloso destino ligado à possessão numinosa, semelhante ao herói trágico, transmudado no discurso filosófico ao personagem socrático, à figura do filósofo dialético que se prepara para a libertaçáo da alma das cadeias corpóreas. 
A evidência socrática de que o aprendizado é reminiscência (mathésis anámnesis) permitiu atestar a natureza ingênita e incorrupta da alma remêmora, reportando-nos à concepção da existência das ideias imutáveis e incorpóreas, de maneira que podemos discernir, no diálogo, quatro tópicos precípuos relativos à epistemologia platônica, correlatos (i) à teoria do saber pré-natal, (ii) à tese da alma imperecível, (iii) à assunção de ideias incorpóreas e (iv) à afinidade ontológica entre a alma e as ideias, com os quais Platão constituirá o discurso verdadeiro, opondo-se aos gêneros produtores de discursos antilógicos e erísticos, aos imitadores fantásticos e àqueles doxásticos. A concepção do aprendizado remêmoro, registrado no Fédon, evidencia a prevalência do discurso verdadeiro ante o presumível discurso persuasivo.

A inspiraçáo socrática do mito remete ao relato órfico do descenso ao Hades, pois Orfeu, com o auxílio de Hermes, desce ao Hades, região invisível, locus inferus, a fim de retirar Eurídice do reino umbrático, território meôntico, sendo o âmbito do olvido. Platão empresta da escatologia órfica, pensada em seus hipotéticos vínculos com o pitagorismo, tanto a imagem da boa rota, identificada à via reta, quanto a imagem da rota a ser evitada, com labirintos e encruzilhadas, nas quais a alma se arrisca a se perder. Configura-se, nas imagens da rota benfazeja e da via sinistra, a remissão às figuras divinizadas da Memória, cuja imagem é Mnemósine, e do Olvido, correlato a Léthe, concebidas como patronas, "[...] esta, da continuidade da expiação por meio dos renascimentos; aquela, da liberação obtida pela mediação da mýesis, cujo papel essencial é atribuído ao noûs." ${ }^{15}$

Repercutem na figuração das rotas benfazeja e sinistra, presentes no mito escatológico do destino das almas, os valores ontológicos atribuídos aos

\footnotetext{
${ }^{15}$ PUGLIESE-CARRATELLI, 2003, p. 17. Jean François Mattéi propóe a classificação dos mitos platônicos em mitos genealógicos e escatológicos, pois esses exprimem "[...] o destino final das almas e seu ulterior renascimento", enquanto aqueles evidenciam [...] "o nascimento do mundo, dos homens e deuses ou remontam à gênese do conhecimento." (MATTÉI, 1996, p. 138). Para ele, a prédica socrática apresenta, a fim de ensinar o destino final das almas e sua palingênese, o trajeto das almas em seu decurso temporal, no âmbito da topografia infraterrenta e supraceleste, exprimindo, pelo prisma normativo jusnaturalista, a justiça cósmica. A récita mítica exposta no epílogo do diálogo é dividida em quatro partes, relativas (i) à analogia entre as regióes terrenhas, às terras ínfera e súpera, (ii) à descrição do sistema hidrográfico subterrâneo, distribuído em quatro rios, (iii) às sançôes póstumas e ao destino final das diversas espécies de alma e, por fim, (iv) à breve conclusão do ensinamento do mito, consolidando o aspecto didascálico e deontológico da mitopoese. A récita mítica sobre o julgamento das almas manifesta o que o discurso lógico veritativo, com seu raciocínio apodítico, não pode evidenciar, de modo que o mito cosmográfico, elaborado pela escrita platônica, se apresenta não como um discurso subordinado à ordem lógica das razóes, porém, como narrativa verossímil, contendo a homologia estrutural com o pensamento lógico.
} 
lados destro e esquerdo do percurso, respectivamente relacionados à ascensão à pátria celeste e ao descenso ao Hades. À descrição minudente do reino ctônico do Hades, com divisão tetrádica dos rios Oceano, Stix, Tártaro e Periflegetonte, se associa o mito escatológico do julgamento final, impondo o lote de cada alma em face de seus numes correspondentes, relacionando-os. A região súpera, âmbito supraceleste, onde habitam os deuses e as formas inteligíveis, se reporta ao ser puro imiscido, correlato à esfera ôntica, enquanto a região ínfera, domínio infernal ctônico e território do esquecimento e antitética ao lugar uraniano, se refere ao não ser absoluto, domínio da privação, de sorte que às topologias cosmográficas corresponderiam os âmbitos ontológicos do ser e do não ser.

Os lugares ôntico e meôntico se ligam à plenitude do inteligível e à sua consequente degradação absoluta no sensível, concernentes à alma filósofa e à alma abjeta. Ressalta-se o nexo evidente entre a hermenêutica política e a hermenêutica cultual, à medida que à reflexão sobre a condição do filósofo, na esfera da pólis, se associa uma especulação palingenética, presente no culto à Mnemósine. Se, no campo político, o saber verdadeiro produz a supressáo da vida, pelo modelo socrático, no campo mítico, âmbito verossímil, promove tanto a bela morte, devido à liberaçáo da alma filósofa do eterno ciclo palingenético, graças à ajuda da respectiva deusa, quanto a eternidade jubilosa, promulgada pela anábase, i.e., pela conversão ao súpero.

A élpis socrática em encontrar os deuses benfazejos no post mortem se atesta nos escritos órficos, precisamente nas lâminas de ouro depositadas sobre os corpos dos mortos, contendo instruçóes para a viagem além tumulo dos iniciados, de forma que a lâmina de ouro mais antiga foi descoberta em 1969, por Ermanno Arslan, na necrópole de Hiponnion, conforme o estudo seminal de Pugliese-Carratelli. Na lâmina em questão, revelada numa tumba funerária de um esqueleto feminino, cuja data remonta provavelmente ao fim do século V ou início do séc. IV a. C., verifica-se, por parte do mýstes, uma predicação a Mnemósine. Realizando o descensus ad inferus, o mýstes, liberto das cadeias corpóreas que antes o aprisionavam, portando-se na regiáo ctônica à direita, onde há uma fonte, certamente Léthe, suplica pela água fresca (psychròn hýdor) que corre do lago de Mnemósine (Mnamosýnas apò límnas). Mas, para bebê-la, os guardiães lhe perquirem, conforme o desígnio do basileu ctônico, por que percorre as trevas do Hades obscuro, respondendo-lhes ser filho da Terra e do Céu estrelado, pedindo-lhes, sedento e desfalecendo, a água fresca proveniente 
do lago da Memória, a fim de percorrer, juntamente com outros mýstai e bácchoi, a via sacra (hodòn hieràn).

Do rito purificatório, observado na lâmina de Hiponion, que conduz o iniciado órfico à via sacra, ao exercício da meléte thánatou, expresso no Fédon, o qual induz Sócrates à segunda navegação, fundando a teoria das Formas, se afere, nesses textos, o traço distintivo sagrado do método, afiançando sensu stricto a dialética, tal como reconhecida por Platão. Preconiza-se, na recepção platônica, um conceito de dialética que excede os limites epistemológicos impostos a posteriori pela racionalidade moderna, a qual cinde os âmbitos da mitopoese e da filosofia. A imagem excelsa da rota benfazeja pode também ser verificada no poema de Parmênides, em que à via das opiniōes dos mortais, onde se manifesta o âmbito meôntico, se contrapóe a via da verdade, de sorte que "[...] a imagem do caminho ou, para dizer de modo mais amplo, a imagem da 'rota' como método de acesso à verdade faz sua entrada de forma definitiva no domínio da filosofia." 16

Pugliese-Carratelli ressalta que a hodòs hierá percorrida pelos mýstai e bácchoi "[...] não tem nada em comum com as outras vias sacras reais, seja a de Elêusis, seja às que conduzem a santuários, ou com as vias imaginárias, como a via percorrida pelo nôेs de Parmênides sobre o carro das Helíades" (PUGLIESE-CARRATELLI, 2003, p. 55), já que conduz para “[...] esferas irreconhecíveis, onde a ausência de toda indicação faz imaginá-las como estranhas a toda experiência deste mundo." (PUGLIESE-CARRATELLI,

${ }^{16}$ CORDERO, Néstor-Luis, 2011, p. 26. De acordo com Bernabé, atesta-se tanto em Empédocles quanto em Píndaro a ideia da hierarquia das metempsicoses, assinalando a transposição das doutrinas órficas para o contexto da filosofia itálica, onde se verifica uma adequação aos propósitos moralizantes dos autores, divergindo, porém, quanto à excelência da vida virtuosa, pois se, para Píndaro, a existência magnânima consiste na vida dos "[...] nobres reis, varôes impetuosos pela força e excelsos pela sabedoria", conforme se alude no Mênon, a fim de referendar a tese da alma imortal, para Empédocles, ela se realiza na "[...] dos augures, poetas, médicos e dirigentes." Discordando das duas referências itálicas, Platão configura a hierarquia das almas nos preceitos de sua dialética, propugnando a vida filosófica como a existência excelsa, reservando aos poetas e aos outros imitadores, aos sofistas, artesãos, aos demagogos e aos tiranos, contraexemplos do dialético, enfim, o pior lote, de sorte que "[...] o fato de que o filósofo seja o ponto mais alto da escalada, antes da libertaçáo final, faz dele o verdadeiro iniciado e purificado'." (BERNABÉ, 2011, p. 176). Com efeito, inexistem, nos textos órficos, propriamente nas lâminas de ouro, nas quais se manifesta o reporte à deusa Mnemósine e analisadas minuciosamente por Pugliese-Carratelli, quaisquer referências à hierarquia das palingêneses, parecendo verossímil a Bernabé pensar que tal ideia "[...] seja uma inovação culta e aristocrática, nascida em âmbito sulitálico e assumida por Empédocles e por Píndaro, que se vê notavelmente desenvolvida e moralizada por Platâo" (BERNABÉ, 2011, p. 176), de modo que não somente no Fedro, referente ao preceito de Adrastea, como igualmente no Mênon, no que diz respeito à palingenesia, a referência culta platônica é a do lírico tebano. 
2003, p. 56). Se há divergências precisas em torno dos caminhos das mencionadas tradiçóes, há um componente específico que os une, relativo à relevância atribuída à Mnemósine, na medida em que se atesta tanto na hodòs hierá do preceito órfico quanto na referência à deusa, contida no proêmio do poema do eleata, que toma a mão direita do viajante com sua mão direita, a alusão, seja explícita, no primeiro caso, seja implícita, no segundo, a Mnemósine, deidade primordial à concepção platônica de alma remêmora. Retendo o gesto da deusa que toma a mão direita do viajante com a sua, o helenista italiano associa às divindades urânias o lado destro, enquanto, pela lógica de oposição, o lado sinistro é vinculado às divindades ctônicas.

A posse de uma sabedoria numinosa permite à alma filósofa o bemaventurado percurso ao Hades, ao descensus ad inferus, de sorte que, tendo permanecido por certo tempo nessa regiáo invisível ctônica, seria reconduzida pela palingenesia à sua união com o corpo, sem padecer dos infortúnios sentidos por uma alma misturada às injustiças e às sediçôes corpóreas. Se a alma se revelar, em seu nexo corpóreo, racional e magnânima, ela se manterá acompanhada sempre de um bom nume, mas, se se mostrar inepta e frívola, padecerá errática no Hades, sem a presença numinosa. A descrição do rito purificatório, da conversão anímica ao Hades e de sua consequente reconversão à vida propicia ao filósofo, cultor das Musas e de Mnemósine, expor a sua concepção cosmográfica, à medida que as almas habitam, na prédica mítica, tanto as regiôes ínferas, dominadas pelo esquecimento e pelas deidades ctônicas, quanto os terrenos súperos, contemplados pela fulgência. Segundo Torrano (TORRANO, 2013, p. 77), "[...] se a filosofia consiste no constante exercício que a antiga tradição denomina purificação, o filósofo é o verdadeiro iniciado, consistindo a sua verdadeira iniciaçáo na purificaçáo, pela qual se eliminam do pensamento todos os elementos sensíveis."

O elogio da alma purificada, cuja natureza incompósita e indestrutível, depurada de elementos sensíveis e realizando o descensus ad inferus retratado em República VII, congenérica à natureza das Formas incorpóreas, revela-se como tanatomeléte, ou seja, como exercício reiterativo para a morte, ressaltando o paradigma expositivo da unidade dos contrários entre a alma e o corpo, firmando o eterno ciclo palingenético e, por conseguinte, entre os gêneros visível e invisível, entre o sensível e o inteligível. 


\section{Consideraçótes Finais}

Não se podem entender os componentes mitopoéticos presentes na prédica escatológica sobre o destino das almas como elementos extrínsecos e extralógicos ao processo dialógico e à exposiçẫo das ideias, concebidos como meros recursos compositivos e simbólicos, alheios à estrutura intelectual, a qual associa o campo conceitual à dimensão imagética do mundo grego clássico. Reitera-se, no movimento do texto em questão, uma acurada definição de alma, conformando os aspectos mítico e epistemológico, ontológico e cultual, dando a ver que o refúgio para os lógoi, em vez de interditar a compreensão humana da dimensão suprassensível pertinente às ideias, explicita a dimensão cognitiva, propriamente noética, da palingênese e de um saber imemorial, atestado na precípua linhagem de autores cara ao filósofo ateniense.

A reflexão deontológica, preceituada por Sócrates, não prescinde da experiência do sagrado, de modo que coexistem no corpus platônico dois âmbitos considerados irreconciliáveis, por parte das categorias modernas de pensamento: a reflexão filosófica e a abordagem cultual. Ressaltam-se, na atividade compositora de Platão, a hermenêutica de categorias fundamentais do pensamento arcaico, promovidas pela racionalidade emergente e por seu acurado esforço de interpretação da tradição e do discurso mitopoéticos, emulando-os devido à própria tradição da agonística grega. A interpretação do Fédon permite aferir o nexo entre experiência cultual e análise racional, de sorte que a passagem do mundo homérico, repousado na comunidade gentilícia mnemônica, para o mundo clássico, fundado na comunidade política, não consiste meramente na transição do discurso figurativo arcaico para o discurso conceitual clássico. $\mathrm{O}$ discurso filosófico, cuja forma completiva na pólis ateniense se realiza nos Diálogos, retém os múltiplos lugares-comuns do discurso mitopoético.

Mediante o quadro hermenêutico proposto, o qual conforma na tecedura comum o âmbito sagrado e a esfera conceitual, se atesta a relevância ontológica e epistemológica concedida à memória e à reminiscência como as funçóes cognitivas estratégicas da alma intelectiva, tal como exposta previamente no Mênon e minudenciada no Fédon, pelo remetimento gnosiológico à estrutura das ideias e à sua relação com o mundo fenomênico, de modo que o refúgio para os lógoi, tese central da ontologia canônica das Formas, não pode ser interpretado como mero limite do saber humano, mas como a via ascensional do filósofo iniciado, epopta, representado por Sócrates, possuidor do saber numinoso. 
RACHID, R. J. R. Reminiscence and reminiscent soul on Plato's Phaedo. Trans/form/açâo, Marília, v. 44, n. 4, p. 327-348, Out./Dez., 2021.

\begin{abstract}
I intend in this article to analyze the epistemological and ontological statute of cognitive soul on Plato's Phaedo in order to clarify its innate ability concerning memory and reminiscence for the constitution of platonic theory of Forms. My purpose here is to demonstrate that Plato's written activity points out the coexistence between figurative discourse and rational discourse, by which he conceives the dialectic between sensible and intelligible genders. Hence, in the first section the research scrutinizes the expression mathésis anámnesis, learning is recollection, observed preliminarily on Meno and Phaedo, as the main epistemological condition to achieve the knowledge of ideas. In the next section I aim to explain how the possession of a numinous wisdom by a reminiscent soul stipulates an original kind of knowing, that cannot be restricted in human boundaries, requiring, for its understanding, a new hermeneutic aproach, which I called cultual hermeneutic. At least, in the last section I will demonstrate that the phenomenological scope of myth foresees a semantic of visibility, by which Plato describes the genuine nature of philosophical logos, represented properly in the socratic compliment of meléte thanátou.
\end{abstract}

KeyWords: Theory of Forms. Ontology. Epistemology. Reminiscent soul. Mythical discourse.

\title{
REFERÊNCIAS
}

BERNABÉ, Alberto. Platáo e o Orfismo, Diálogos entre religião e filosofia. São Paulo: Annablume Clássica, 2011.

BOSTOCK, David. The Soul and Immortality in Plato's Phaedo. In: FINE, Gail (ed.). Plato 2: Ethics, Politics, Religion and the Soul. Oxford: OUP, 1999. p. 404-424.

BRISSON, Luc. Platon, Pythagore et les Pythagoriciens. In: DIXSAUT, Monique (org.). Platon, Source des Présocratiques: Exploration. Paris: Jean Vrin, 2002. p. 21-46.

CORDERO, Néstor-Luis. Sendo, se é, a tese de Parmênides. Tradução de Eduardo Wolf. São Paulo: Odysseus, 2011.

DIXSAUT, Monique. Métamorphoses de la dialectique dans les Dialogues de Platon. Paris: Jean Vrin, 2001.

DIXSAUT, Monique. Platon, le désir de comprendre. Paris: Jean Vrin, 2003.

HUFFMAN, Carl. Limite et illimité chez les premiers philosophes grecs. In: DIXSAUT, Monique (org.). La fêlure du plaisir. Études sur le Philebe de Platon. 2: Contexts. Paris: Jean Vrin, 1999. p.11-31.

KAHN, Charles. Plato and the Socratic Dialogues: the philosophical use of a literary form. Cambridge: CUP: 1996. 
KAHN, Charles. La Philosophie de Socrate selon Platon et Aristote. In: DHERBEY, Gilbert Romeyer (org.). Socrate et les Socratiques. Paris: Jean Vrin, 2001. p. 207-240. MATTÉI, Jean François. Platon et le miroir du mythe, de l'âge d'or à l'Atlantide. Paris: PUF, 1996.

MIÉ, Fabián. Lenguage, Conocimiento y Realidad en la Teoría de las Ideas de Platón. Investigaciones sobre los diálogos medios. Córdoba: Ed. del Copista: 2004.

PLATÃO. Mênon. Texto estabelecido e anotado por John Burnet. Tradução de Maura Iglésias. São Paulo: Loyola, 2005.

PLATON. Phédon. Texte établi et traduit par Léon Robin. Paris: Les Belles Lettres, 2005.

PLATON. Phédon. Traduction, introduction et notes par Monique Dixsaut. Paris: GF Flammarion, 1991.

PUGLIESE-CARRATELLI, Giovanni. Les lamelles d'or orphiques: instructions pour le Voyage d'outre-tombe des initiés grecs. Paris: Les Belles Lettres, 2003.

TORRANO, J. A. A. O pensamento mítico no horizonte de Platáo. São Paulo: Annablume Clássica, 2013.

TORRANO, J. A. A. Mito e imagens míticas. São Paulo: Córrego, 2019.

VERNANT, Jean Pierre. Aspectos míticos da memória e do tempo. In: VERNANT, Jean Pierre Mito e Pensamento entre os Gregos. São Paulo: Paz \& Terra, 1990. p. 133-186.

VLASTOS, Gregory. Anamnesis in the Meno. In: DAY, Jane M. (ed.). Plato's Meno in focus. London \& New York: Routledge, 1971. p. 88-111.

VLASTOS, Gregory. Platonic Studies. Princeton: Princeton University Press, 1994.

Recebido: 16/6/2020

Aceito: $13 / 5 / 2021$ 